\title{
FORTY-TWO HITHERTO UNRECOGNIZED GENERA AND SUBGENERA OF ZYGOPTERA.
}

\author{
Clarence Hamilton Kennedy, \\ Ohio State University.
}

During the past five years the writer has been engaged in a revision of the genera of the Zygoptera. The following new genera and subgenera have been in manuscript form for from two to five years. In nearly every case the characters of the penis have been the primary indicators that a new generic term might be advisable. In nearly every case other characters, usually venational, were found to parallel the penis characters.

The writer has attempted to give the genus a value which as nearly as possible represents the same amount of differences in whatever part of the Zygopterous series it might fall. This ideal was not altogether attainable, because genera have been split so very fine in the Agrioninæ and some of the other very modern groups. Even in these groups, however, the genera are not as close as in some sections of the Libellulidæ, where connecting links have not yet dropped out.

No apologies are offered for the series of monotypic genera. These in nearly all cases are annectant forms, the last fragments. of faunas preceding the present.

Full descriptions of these new genera and subgenera with an extended discussion of their relationships as shown by the genitalia will eventually appear, the author hopes, as a bulletin of the U. S. National Museum.

\section{Vestinus genus nov.}

Type-Vestalis (Calopteryx) gracilis Ramb.

This new genus includes Vestalis amoena Selys. It differs from Vestalis (type luctuosa) in that the lobes of the penis are approximated and parallel, $\mathrm{M}_{3}$ and $\mathrm{M}_{4}$ arise at the same point on the arculus; there are never two complete rows of cells between $\mathrm{Cu}_{1}$ and $\mathrm{Cu}_{2}$ and the wings are hyaline.

Anaciagrion genus nov.

Type-Agrion (Calopteryx) cornelia Selys.

This new genus includes the single beautiful species cornelia. It differs from Agrion in that $\mathrm{Cu}_{2 \mathrm{a}}$ is $5-6$ cells long, as against. a length of 2-4 cells in Agrion and is directed entad and caudad towards the anal field of the wing. 
Euchlorolestes genus nov.

Type-Chlorolestes fasciata Selys.

This genus includes also Chlorolestes tessellata Burm. and Chlorolestes longicanda Burm. Apical soft fold of penis erect and hoodlike; Ac lies slightly distad of the level of the first antenodal.

Episynlestes genus nov.

Type-Synlestes albicanda Tilly.

Quadrilateral broad, its inner end one-third of the hind side, first segment of $\mathrm{Cu}_{2}$ present. Penis with a long attenuate tip.

Ceylonolestes genus nov.

Type-Austrolestes analis Ramb.

Includes also aridus, colensonis, cyaneus, divisus, gracilis, leda and tenuissimus. Naiad with lateral lobe as in the naiad of Lestes, at least so in analis. Penis with a spiral strap on the terminal lobe.

Chalcolestes genus nov.

Type-Lestes viridus Lind.

Differs from Lestes in that the upper segment of the arculus equals the lower and that the penis lacks the internal fold.

Africalestes genus nov.

Type-Lestes virgatus Burm.

Venation as in Chalcolestes, except that vein $\mathrm{M}_{\mathrm{a}_{\mathrm{a}}}$ is nearly straight throughout its length. Penis with a strap-like inner fold as in Ceylonolestes.

Platystigma genus nov.

Type-Mecistogaster jocaste Hagen.

Penis with a broad, toothed terminal segment. Dense black part of stigma reduced to one cell in hind wing.

Xanthostigma genus nov.

Type-Mecistogaster ornatus Ramb.

Includes ornatus and its varieties. Penis with a broad linear terminal segment without lateral teeth. Black part of stigma lacking in both wings.

Haplostigma genus nov.

Type-Mecistogaster modestus Selys.

Penis with terminal fold united to the apical segment. Dense part of stigma.more than three cells long. Hind wing of male without costal dilation before apex. 
Goniostigma genus nov.

Type-Mecistogaster amalia Burm.

Costal dilation of male hind wing angulate. Penis with a large internal hood.

Proplatycnemis genus nov.

Type-Platycnemis hova Selys.

Includes also agrioides Ris. Differs from Platycnemis in that $M_{2}$ arises at postnodal 6-7 in front wing and at 4 in hind wing and that the stigma is longer than the cell below it.

Leptargia subgenus nov.

Type-Argia mollis Hagen.

Includes fosteri, croceipennis, subapicalis, reclusa, tinctipennis, chapadce, sociale, smithiana, botacudo, tamoyo, tupi, hasmani, sordida, thespis, tinctipennis.

Internal soft fold of penis lacking, terminal segment flagel1ate. South American.

Micrargia subgenus nov.

Type-Argia thisma Calvert.

Includes also lilacina. Terminal segment of penis saggitate.

Heliargia subgenus nov.

Type-Argia vivida Hagen.

Includes also plana, funebris, immunda, deami, probably also talamanca, underwoodi and terira.

Internal fold of penis small or wanting, terminal segment irregularly triangular or even with a short attenuate tip. External fold present.

Cyanargia subgenus nov.

Type-Argia lacrymans Hagen.

Includes also tonto. Penis with a flagellum attached to inner surface of terminal segment.

Chalcargia subgenus nov.

Type-Argia oenea Hagen.

Includes also orichalcea, harknessi, barreti, calida, percellulata, insipida, ulmeca, adamsi, pipila, oculata, difficilis, rogersi, jocosa, tezpi, translata, sedula, gerhardi, frequentula, cuprea, pulla, nigrior, indicatrix, gaumeri, popoluca, cupraurea, johanella.

Penis with apex bifid.

Argyrocnemis genus nov.

Type-Agriocnemis argentea Tillyard.

Penis with edges of terminal segment serrate, male superior appendages with hollow tips. 
Neoerythromma genus nov.

Type-Enallagma cultellatum Selys.

Penis characters as in Erythromma, but male appendages resembling those in Enallagma signatum.

Psenderythromma genus nov.

Type-Erythromma viridulum Charp.

Like Erythromma except male appendages Psendagrion-like and wing with only 10-11 postnodals and 3 antenodal ultraquadrilateral cells.

Austrocoenagrion genus nov.

Type-Coenagrion lyelli Tilly.

Like Coenagrion except penis with shaft spines and the internal soft fold hood-like. Venation not studied.

\section{Hawaiiagrion genus nov.}

Type-Megalagrion (Coenagrion) xanthomelas Selys.

Characters as in Coenagrion, but colors are reds and yellows, and the male appendages are Psendagrion-like. Includes deceptor, calliphya, nigrohamatum, vagabundum, molokaiense, microdemas and others.

Kilauagrion genus nov.

Type-Megalagrion (Coenagrion) nesiotes Perkins.

Generic characters as in Hawaiiagrion, except that the male superiors are long and forcipate.

Oahuagrion genus nov.

Type-Megalagrion (Coenagrion) oahuense Blackburn.

Generic characters as in Hawaiiagrion, except that the stigma in hind wing of male is placed one and a half times as far from the wing apex as is the stigma of the front wing, slightly less so in the female.

Apanisagrion genus nov.

Type-Anisagrion lais Selys.

Characters as in Anisagrion, except that the wing is not petioled to $A c$ by a distance equal to the length of $A c$ and the apex of segment 10 in the male is not forked.

\section{Protallagma genus nov.}

Type-Amphiagrion titcace Calvert.

Characters as in Enallagma, except that the colors are largely red and the apex of segment 10 in the male is merely notched; i. e., without the two tubercles. 
Oxyallagma genus nov.

Type-Oxyagrion dissidens Selys.

Characters as in Enallagma, except red a dominant color, no postocular spots and penis without lateral basal lobes.

\section{Africallagma genus nov.}

Type-Enallagma glaucum Burm.

Generic characters as in Enallagma, except apex of segment 10 in male is elevated into an apical keel, notched at apex. Includes nigridorsum, obliteratum and schultzei as described by Ris, "Od. Sudafrika."

\section{Cyanallagma genus nov.}

Type-Acanthagrion interruptum Selys.

Characters as in Acanthagrion, except the male superior appendages not decurved from the base and are usually forked.

Includes laterale, acutum and perhaps cheliferum.

\section{Archaeallagma genus nov.}

Type-Enallagma ovigerum Calvert.

Characters as in Enallagma, except that the hind edge of the prothorax with a rectangular lobe.

\section{Mesamphiagrion genus nov.}

Type-Enallagma occultum Ris.

Characters as in Enallagma, but body colors red, apex of segment 10 elevated and notched, body long haired and stigma one-half cell long. Differs from Amphiagrion in male appendages being Enallagma-like, in postocular spots, in lacking the metasternal tubercles.

Teleallagma genus nov.

Type-Telagrion daecki Calvert.

Characters as in Enallagma, but the pair of subdorsal apical points of segment 10 are widened laterally into minute lobes, abdomen very slender. Wings petioled to Ac.

\section{Ischnallagma genus nov.}

Type-Ischnura elongata Martin.

Venation and stigmas as in Ischnura, apex of ten forked, male appendages and penis as in Enallagma.

\section{Proischnura genus nov.}

Type-Enallagma subfurcatum Selys.

Characters as in Enallagma, except stigmas of hind wings smaller than those of front wings. Apex of segment 10 in male 
forked. Penis intermediate between that of Ischnura and that of Enallagma.

\section{Homeoura genus nov.}

Type-Ischnura neops Selys.

Characters as in Ischnura, but more Enallagmine. Proximal and distal sides of stigmas rounded, costa slightly indent $d$ at stigma. Penis with large lateral paches of spines on the second segment.

\section{Anomalura genus nov.}

Type-Ischnura prognatha Hagen.

Characters as in Ischnura, except the apical fork of segment 10 in the male is elongated into a spine, the paired spines of the penis are external as in Anomalagrion.

Nanosura genus nov.

Type-Ischnura aurora Braner.

Characters as in Ischnura, except male with a pair of mesothoracic hook-like horns.

\section{Amphiallagma genus nov.}

Type-Enallagma parvum.

Characters as in Amphiagrion, except post ocular spots present, colors blue and black; body not heavily haired.

Seychellibasis genus nov.

Type-Telebasis allaudi Martin.

Characters as in Teinobasis, except anal plate in male not elongate. Apical lobe of penis linear.

Palaeobasis genus nov.

Type-Pyrrhosoma tenellum Vill.

Characters as in Ceriagrion, except that wings are not petioled to Ac.

Diceratobasis genus nov.

Type-Agrion macrogaster Selys.

Characters as in Metaleptobasis, but male without thoracic horns, while a large pair of horns occur on the seminal vesicle.

Aceratobasis genus nov.

Type-Metaleptobasis cornicauda Calvert.

Characters as in Metaleptobasis, but male without thoracic horns and his superiors longer than the inferiors. 